\title{
Penggunaan Model Blended Learning dalam Mata Pelajaran Bahasa Indonesia di Era Normal Baru
}

\section{The Use of Blended Learning Model of Indonesian Lesson in the New Normal Era}

\section{Faridah Eriyaningsih ${ }^{1,}$, , Haryadi ${ }^{2}$, dan Agus Nuryatin ${ }^{3}$}

1,2,3 Pascasarjana Universitas Negeri Semarang Jalan Kelud Utara III, Semarang, Jawa Tengah, Indonesia

1, ${ }^{\star}$ Email: faridaheriyaningsih@gmail.com; Orcid: https://orcid.org/0000-0002-3066-695X

2Email: haryadihar67@mail.unnes.ac.id; Orcid: https://orcid.org/0000-0002-2355-858X

3 Email: agusnuryatin@mail.unnes.ac.id; Orcid: https://orcid.org/0000-0002-8462-6187

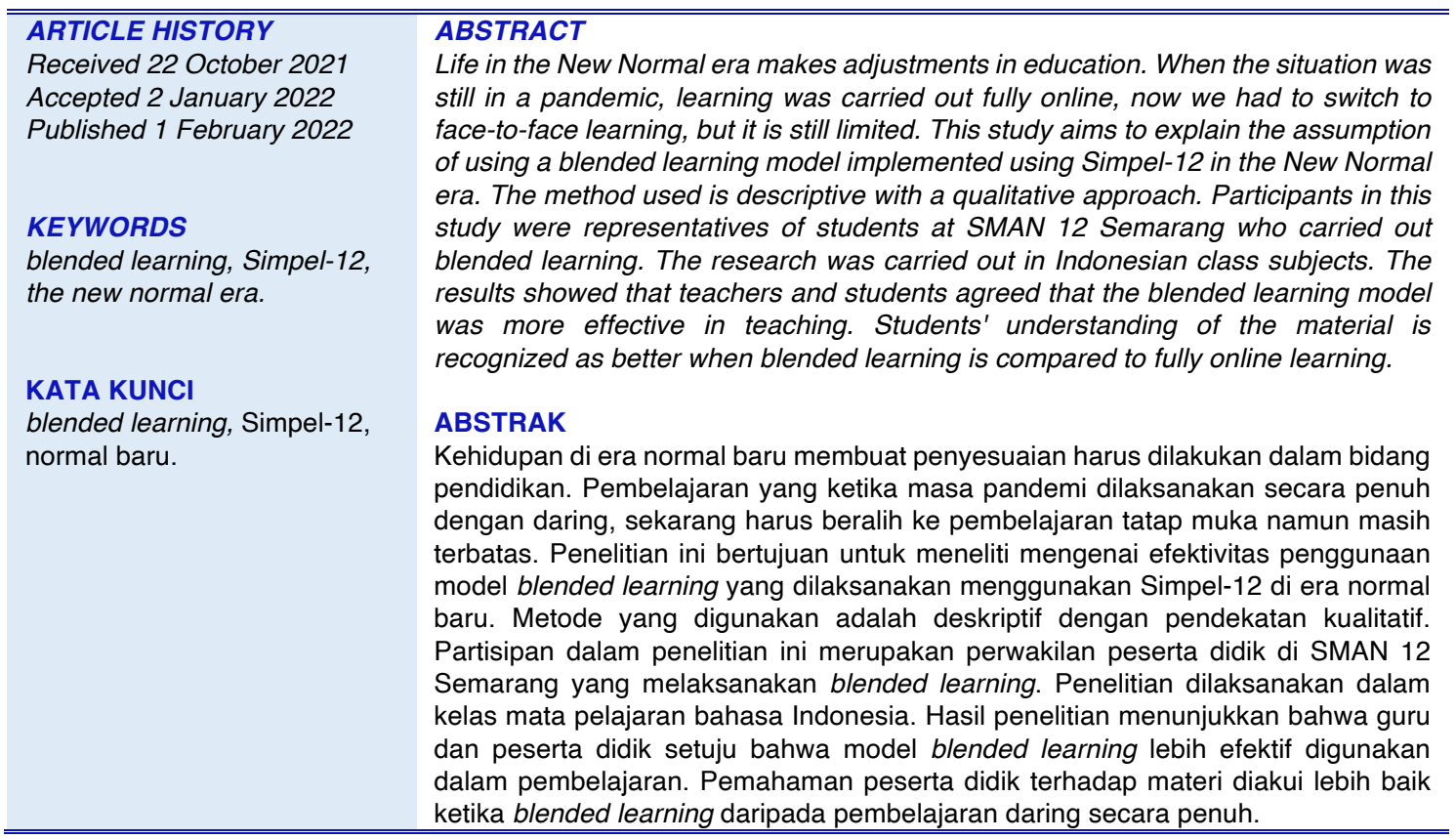

To cite this article:

Eriyaningsih, F., Hariyadi, H., \& Nuryatin, A. (2022). Penggunaan Model Blended Learning dalam Mata Pelajaran Bahasa Indonesia di Era Normal Baru. Diglosia: Jurnal Kajian Bahasa, Sastra, dan Pengajarannya, 5(1), 153-162. https://doi.org/10.30872/diglosia.v5i1.315 


\section{A. Pendahuluan}

Pada awal tahun 2020, seluruh dunia digemparkan oleh sebuah virus yang menyerang pernapasan manusia. Virus tersebut menyebar secara masif dan menjadi sebuah pandemi. Dalam KBBI V dijelaskan bahwa pandemi merupakan wabah yang berjangkit serempak di mana-mana, meliputi daerah geografi yang luas. Sebagian besar negara di dunia melakukan lockdown. Hal tersebut tentunya memberikan dampak ketidakstabilan dalam berbagai bidang, mulai dari bidang politik, ekonomi, pariwisata, serta bidang pendidikan. Sistem pembelajaran yang telah berlaku tentunya harus dipaksa mengalami perubahan secara tiba-tiba. Selama lebih dari satu tahun mulai dari Maret 2020 pembelajaran dilakukan secara daring. Strategi pembelajaran yang digunakan juga pastinya berbeda dengan ketika pembelajaran tatap muka. Pada bidang pendidikan, keadaan pandemi ini membuat semua manusia harus siap dengan perkembangan teknologi. Pendidik harus menguasai mode pembelajaran berbasis teknologi agar dapat menciptakan model atau metode baru untuk pelaksanaan pembelajaran (Siahaan, 2020).

Seiring berjalannya waktu selama masa pandemi, pembelajaran bahasa dan sastra Indonesia dengan model jarak jauh dirasa kurang efektif. Penyampaian materi pembelajaran bahasa Indonesia melalui pembelajaran jarak jauh tidak berjalan sebaik pembelajaran tatap muka. Bahasa Indonesia secara psikologis memiliki peran yang sangat vital bagi pembelajaran. Melalui pembelajaran bahasa Indonesia, peserta didik bisa mengomunikasikan pengetahuan maupun gagasannya dengan baik (Nilasari, 2020).

Pada buku teks bahasa Indonesia di kurikulum 2013 Kemdikbud juga disebutkan bahwa bahasa Indonesia merupakan penghela ilmu pengetahuan. Bahasa Indonesia merupakan pengantar pembelajaran bidang ilmu atau mata pelajaran lain. Untuk itu, sudah seharusnya pembelajaran bahasa Indonesia dipahami anak dengan baik. Kompetensi dasar pembelajaran bahasa Indonesia yang diajarkan di sekolah mencakup empat keterampilan berbahasa, yaitu menyimak, membaca, berbicara dan menulis. Menyimak merupakan proses pertama dalam keterampilan berbahasa (Tarigan, 2008b). Sedangkan membaca sebagai proses pengenalan dan penyandian kembali simbol-simbol tertulis, dan memberikan reaksi kritis terhadap bacaan dalam menentukan signifikasi, nilai, fungsi yang dipaparkan penulis (Haryadi, 2012).

Menyimak dan membaca termasuk dalam keterampilan reseptif yang berguna untuk menerima suatu informasi. Selanjutnya, dua keterampilan berbahasa lainnya, yaitu menulis dan berbicara termasuk ke dalam keterampilan berbahasa produktif. Menulis adalah salah satu keterampilan berbahasa produktif yang dipergunakan untuk berkomunikasi secara tidak langsung dan tidak secara tatap muka dengan pihak lain. Berkaitan dengan hal tersebut keterampilan menulis sulit dikuasai karena keterampilan menulis menghendaki penguasaan berbagai unsur kebahasaan dan unsur luar bahasa itu sendiri (Mahmud, 2017).

Walaupun sama-sama kemampuan produktif berbicara memiliki pengertian yang berbeda dengan menulis. Berbicara adalah kemampuan mengucapkan 
bunyi-bunyi artikulasi atau kata-kata untuk mengekspresikan pikiran, gagasan dan perasaan (Tarigan, 2008a). Guru bahasa Indonesia di sekolah memiliki peranan yang sangat penting agar peserta didik dapat memiliki dan menguasai empat keterampilan berbahasa tersebut selama masa pandemi. Sejalan dengan penjelasan oleh Yanti et al. (2018) bahwa untuk menghasilkan peserta didik yang memiliki keterampilan berbahasa yang baik maka dibutuhkan juga seorang guru bahasa yang profesional dan memiliki kemampuan serta menguasai keterampilan berbahasa. Hal tersebut tentunya juga harus didukung dengan strategi pembelajaran yang tepat dalam keadaan tersebut.

Seiring dengan tingkat vaksinasi yang dilakukan semakin tinggi, pemerintah pun memberlakukan kehidupan normal baru (new normal). Normal baru merupakan kehidupan manusia yang berusaha hidup berdampingan dengan covid-19. Penelitian yang dilakukan Firmansyah \& Kardina (2020) menunjukkan bahwa normal baru sangat berpengaruh bagi berlangsungnya pendidikan. Seiring diberlakukannya normal baru, tempat-tempat umum yang dapat dikunjungi masyarakat mulai dibuka. Dimulai dari pasar, pusat perbelanjaan, tempat layanan sosial, dan juga tempat pendidikan. Suyanta (Sekretaris Dinas Pendidikan dan Kebudayaan Provinsi Jawa Tengah) menyampaikan melalui laman pemerintah Provinsi Jawa Tengah bahwa pada akhir Agustus 2021 sekolah boleh melakukan pembelajaran tatap muka terbatas pada zona-zona yang telah ditentukan sesuai aturan kementerian, yaitu pada zona satu dan dua. Pembelajaran tatap muka ini tidak dilakukan oleh seluruh peserta didik, namun oleh beberapa perwakilan dengan kriteria yang telah ditentukan oleh pemerintah. Hal ini tentu membuat beberapa perubahan dalam strategi pembelajaran yang harus dilakukan, khususnya dalam membelajarkan keterampilan berbahasa Indonesia kepada peserta didik. Untuk itu, pembelajaran di SMAN 12 menggunakan model blended learning. Pembelajaran bahasa Indonesia model blended learning haruslah didukung oleh sarana dan prasarana serta media yang baik.

SMAN 12 Semarang menggunakan platform pembelajaran Simpel-12 untuk pelaksanaan seluruh pembelajarannya. Pembelajaran bahasa Indonesia juga dilakukan dengan menggunakan platform simpel 12 dengan didukung aplikasi untuk video conference. Dalam pelaksanaannya, tentunya masih banyak kelebihan dan kekurangan yang terjadi. Pada pelaksanaan pembelajaran bahasa Indonesia dengan model blended learning juga ditemukan beberapa peserta didik yang menganggap model pembelajaran ini belum efektif karena tidak dapat mengakomodasi kebutuhan belajar peserta didik yang di rumah atau melakukan pembelajaran jarak jauh (PJJ). Oleh karena itu, tujuan penelitian ini adalah untuk menjelaskan penggunaan model blended learing dalam pembelajaran bahasa Indonesia saat pelaksanaan pembelajaran tatap muka terbatas (PTMT) di era normal baru yang dilaksanakan melalui platform Simpel-12.

\section{B. Metode}

Penelitian ini merupakan penelitian deskriptif yang menggunakan pendekatan kualitatif. Sugiyono (2017) menjelaskan bahwa penelitian kualitatif 
digunakan untuk meneliti kondisi objek yang alamiah dan peneliti sebagai instrumen kuncinya. Sumber data juga diambil dari wawancara dengan partisipan. Partisipan merupakan peserta didik di SMAN 12 Semarang yang sedang melakukan pembelajaran dengan model blended learning, yaitu kelas $X$ IPS 3, XI MIPA 1, dan XII BB. Kelas-kelas tersebut dipilih berdasarkan perwakilan jenjang kelas dan penjurusannya. Jumlah partisipan seluruhnya adalah 88 anak. Persentase blended learning adalah 50:50, yaitu 50\% tatap muka terbatas dan $50 \%$ pembelajaran jarak jauh (pembelajaran daring). Tiap kelas tersebut terdiri atas 18 orang yang mengikuti pembelajaran tatap muka terbatas (PTMT) dan 18 orang yang mengikuti pembelajaran jarak jauh (PJJ). Peneliti membuat angket yang diberikan kepada partisipan untuk dijawab dan juga membuat pedoman wawancara untuk guru pengajar bahasa Indonesia. Observasi juga dilakukan dengan cara mengikuti secara langsung pembelajaran dengan model blended learning. Analisis data menggunakan model dari Miles \& Huberman, yaitu dengan pengumpulan data, reduksi data, penyajian data, dan simpulan atau verifikasi.

\section{Pembahasan}

Pelaksanaan pembelajaran di masa normal baru membutuhkan kecerdasan dari pendidik untuk menemukan strategi pembelajaran yang baik. Model yang muncul kembali saat ini adalah model blended learning. Blended learning di era modern merupakan suatu kepastian yang harus dilaksanakan mengingat situasi di mana komunikasi tatap muka seperti pada keadaan sebelum pandemi tidak memungkinkan (Hilmi \& Ifawati, 2020). Saat ini model tersebut banyak digunakan dalam pembelajaran di sekolah selama era normal baru.

Blended leraning bukanlah model yang asing bagi pendidikan abad-21. Pada tahun 2021, model blended learning disarankan oleh Kemdibud sebagai salah satu strategi pembelajaran di era normal baru. Pada dasarnya, model blended learning menggabungkan tatap muka dengan teknologi modern dan dipandang efektif untuk semua pihak dengan persiapan yang matang (Hilmi \& Ifawati, 2020). Hal tersebut juga sejalan dengan pemikiran (Halimah, 2019) bahwa pembelajaran blanded learning, memanfaatkan media menggunakan fasilitas internet, memadukan strategi daring dan luring, sehingga ada dua komponen utama dalam desain pembelajaran blanded learning, yaitu sistem pembelajaran yang dilakukan secara tatap muka dan daring. Dwiyogo (2019) menjelaskan makna asli yang sering digunakan dalam menjelaskan blended learning adalah belajar yang mengombinasikan pembelajaran tatap muka (face to face) dan pembelajaran berbasis komputer (online dan offline). Menjadi semakin jelas bahwa pembelajaran dengan blended learning dapat mengatasi berbagai keterbatasan terkait pembelajaran jarak jauh (pembelajaran daring) dan pengajaran tatap muka (Alammary et al., 2014). Graham (2006) menjelaskan dalam handbook-nya mengenai blended learning system bahwa terdapat enam isu utama yang relevan dengan perancangan sistem blended learning. Isu-isu tersebut, yaitu (1) peran interaksi langsung, (2) peran pilihan pelajar dan pengaturan diri, (3) model untuk dukungan dan pelatihan, (4) temuan 
keseimbangan antara inovasi dan produksi, (5) adaptasi budaya, dan (6) berurusan dengan kesenjangan digital. Isu yang yang mendukung dalam era normal baru ini adalah isu pertama.

Pada setiap model pembelajaran, memiliki sintak yang harus dilakukan. Model blended learning memiliki 6 sintak, yaitu (1) orientasi pembelajaran; (2) mengakses materi dan aktivitas konten; (3) proyek penugasan kelompok; (4) diskusikan secara offline dan online untuk pemantauan proyek; (5) menguji hasil proyek secara tatap muka di kelas; dan (6) evaluasi. Pendekatan pembelajaran dengan menerapkan model tersebut adalah melalui pembelajaran yang berpusat pada peserta didik, yang mendorong peserta didik untuk belajar secara mandiri dan mampu mengonstruksi pengetahuannya sendiri (Jalinus et al., 2021). Melalui sintaks tersebut, peserta didik dapat melakukan pembelajaran dengan proaktif. Peserta didik melakukan pembelajaran secara bertatap muka di sekolah dan juga dalam waktu yang bersamaan melakukan pembelajaran daring di rumah. Peserta didik yang melakukan tatap muka (TPM) terbatas di sekolah dan peserta didik yang melakukan pembelajaran jarak jauh (PJJ) dapat mengakses konten yang sama yang diberikan oleh guru. Peserta didik secara bersamaan juga dapat melakukan diskusi mengenai suatu materi pembelajaran melalui model ini. Hal ini tentunya lebih memudahkan peserta didik dalam melaksanakan pembelajaran di era normal baru.

Hendarrita et al. (2018) menjelaskan dalam model pembelajaran blended learning terdiri atas tiga komponen penting, yaitu (1) online learning, (2) pembelajaran tatap muka, dan (3) belajar mandiri. Kanuka \& Rourke (2013) menjelaskan bahwa kemungkinan keuntungan dari penggunaan model blended learning untuk pengembangan pengajaran ada dua, yaitu memberikan kesempatan untuk belajar dari pengalaman dan mengembangkan rasa komunitas. Guru atau pendidik tidak hanya belajar dari pengalamannya saja, namun mereka juga dapat belajar dari sudut pandang peserta didik. Hal ini tentunya menjadi kesempatan yang baik pula bagi guru. Banyak guru yang masih tidak dapat menggunakan teknologi untuk mendukung pembelajaran. Dengan adanya model blended learning ini guru secara tidak langsung dipaksa untuk belajar dan meningkatkan kemampuannya atas penguasaan teknologi. Keuntungan lain yang telah disebutkan adalah mengembangkan rasa komunitas. Rasa komunitas ini dapat diartikan sebagai rasa kebersamaan antarteman. Pembelajaran daring sepenuhnya tentu saja membuat peserta didik sangat jenuh. Indikator kejenuhan tersebut dapat dilihat dari penelitian yang dilakukan oleh Pawicara \& Conilie (2020) yang menyebutkan bahwa kejenuhan dapat dilihat melalui aspek kelelahan emosi, kelelahan fisik, kelelahan kognitif, dan kehilangan motivasi.

Simpel-12 merupakan sebuah e-learning yang dikembangkan oleh SMAN 12 Semarang selama masa pandemi ini. E-learning dapat menjadi pilihan dalam pelaksanaan pembelajaran jarak jauh karena berbasis internet yang tidak menuntut peserta didik dan guru untuk datang ke sekolah (Triyanto, 2020). Simpel-12 ini dikembangkan pada pertengahan tahun 2020 untuk mendukung pembelajaran jarak jauh (pembelajaran daring) agar tetap dapat mencapai tujuan pembelajaran yang baik. Simpel-12 merupakan sebuah website yang dapat 
digunakan untuk pembelajaran synchronous maupun asynchronous. Jadi, platform pembelajaran tersebut dapat mendukung penggunaan model blended learning dalam pembelajaran khususnya di era normal baru yang banyak melalukan pembelajaran synchronous. Pembelajaran synchronous merupakan pembelajaran di mana peserta didik dan instruktur dapat bertukar informasi dan berinteraksi secara bersamaan dalam sebuah komunitas pembelajaran daring secara langsung melalui teknologi pembelajaran termasuk internet conference, satelit, telekonferensi video dan chatting (Narayana, 2016). Pelaksanaan blended learning, pada pembelajaran bahasa Indonesia di SMAN 12 Semarang menggunakan Simpel-12 sebagai medianya. Melalui platform tersebut, guru dan peserta didik dapat melaksanakan pembelajaran tatap muka dan pembelajaran daring secara bersamaan. Berdasarkan wawancara dengan guru bahasa Indonesia di sana model blended learning dirasa sangat membantu dalam peningkatan belajar peserta didik. Dibanding dengan pembelajaran jarak jauh sepenuhnya, model blended learning lebih efektif. Anak-anak di sini juga lebih antusias untuk PTM di sekolah.

Berdasarkan penelitian yang telah dilakukan melalui penyebaran angket untuk mengetahui pendapat peserta didik di SMAN 12 Semarang terhadap pelaksanaan blended learning di sekolahnya, terdapat tujuh poin yang ditanyakan oleh peneliti, yaitu sebagai berikut.

a. Penggunaan model blended learning membantu dalam memahami pembelajaran mata pelajaran bahasa Indonesia.

b. Penggunaan model blended learning yang dikombinasikan dengan platform Simpel-12 nyaman digunakan untuk pembelajaran tatap muka terbatas.

c. Penggunaan model blended learning yang dikombinasikan dengan platform Simpel-12 nyaman digunakan untuk pembelajaran jarak jauh.

d. Pemahaman pada pembelajaran bahasa Indonesia lebih baik ketika pembelajaran tatap muka terbatas dibandingkan dengan ketika pembelajaran jarak jauh.

e. Ketika pembelajaran bahasa Indonesia dengan model blended learning, guru menjelaskan pembelajaran untuk yang di rumah dan juga di sekolah.

f. Fasilitas pembelajaran (HP/Laptop) dan jaringan internet mendukung untuk pemberlakuan model blened learning.

g. Pembelajaran bahasa Indonesia dilakukan dengan penyajian materi yang menarik.

Hasil penelitian yang telah dilakukan mengenai penggunaan blended learning dengan Simpel-12 pada mata pelajaran bahasa Indonesia di era normal baru dapat dilihat pada Gambar 1. 


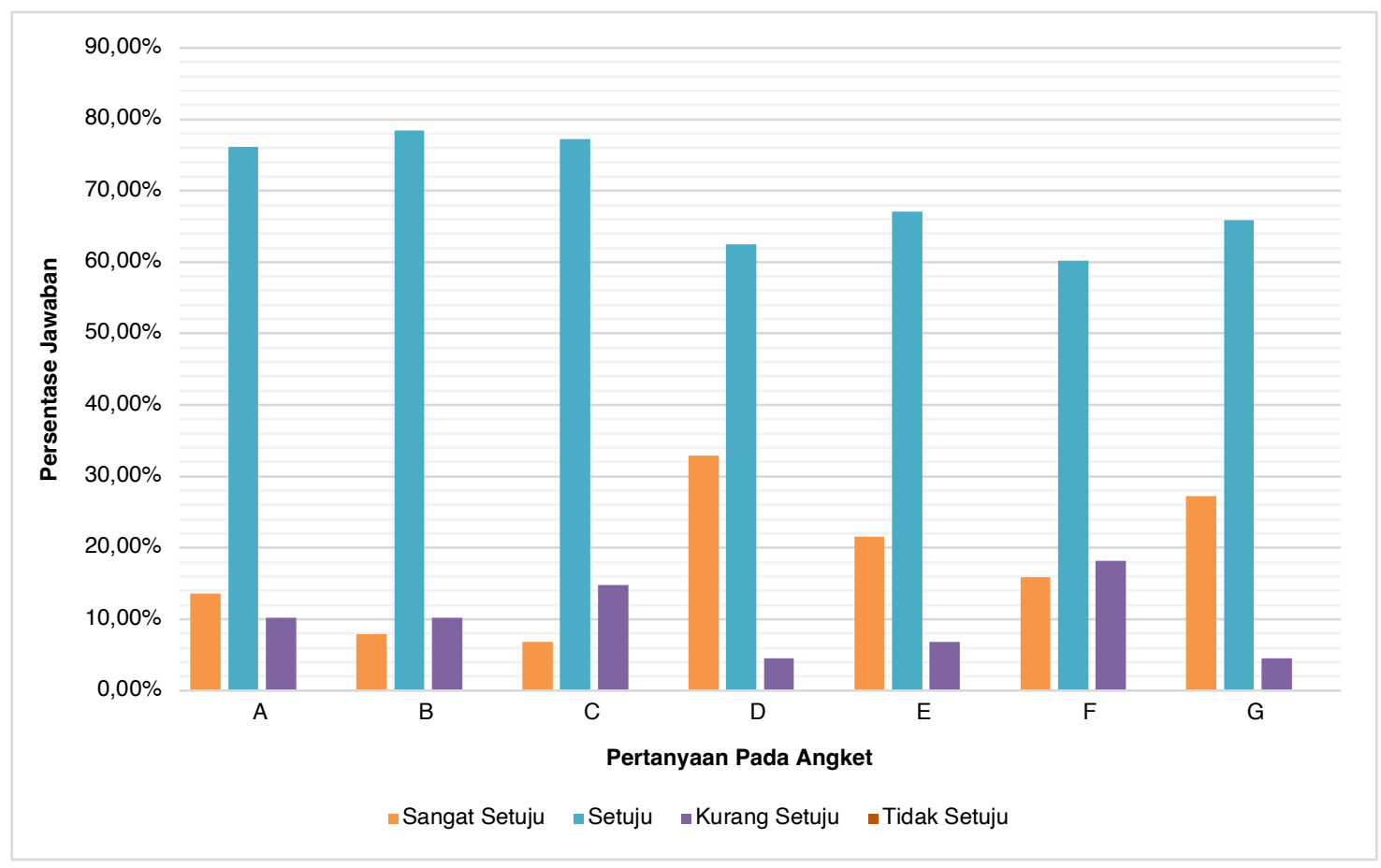

\section{Gambar 1. Persentase Penerapan Model Blended Learning dengan Simpel-12}

Berdasarkan data hasil penelitian sebagaimana grafik pada Gambar 1, diperoleh hasil sebagai berikut. Pertama, sebagian besar peserta didik menyetujui bahwa model blended learning lebih membantu dalam memahami pembelajaran mata pelajaran bahasa Indonesia. Hal ini dikarenakan guru menjelaskan secara langsung melalui live meet kepada peserta didik yang di sekolah, maupun di rumah. Masih terdapat peserta didik yang memilih tidak setuju. Berdasarkan penelitian yang dilakukan, peserta didik yang menjawab kurang setuju adalah peserta didik yang melakukan pembelajaran secara daring dan perangkatnya tidak mendukung serta peserta didik yang kemampuan akademiknya diakui kurang baik. Kedua, penggunaan model blended learning yang dikombinasikan dengan platform Simpel-12 membuat nyaman dalam pembelajaran anak-anak ketika pembelajaran tatap muka terbatas di sekolah. Hal ini dikarenakan peserta didik tidak perlu seharian belajar melalui HP atau laptop, namun dapat bertatap muka secara langsung dengan guru. Peserta didik yang memilih kurang setuju sebanyak $10.23 \%$ adalah peserta didik yang melakukan daring. Ketiga, penggunaan model blended learning yang dikombinasikan dengan platform Simpel-12 juga disetujui oleh sebagian peserta didik nyaman digunakan dalam pembelajaran jarak jauh. Keempat, penggunaan model blended learning disetujui dan bahkan sangat disetujui oleh peserta didik membuat pemahamannya meningkat terhadap mata pelajaran bahasa Indonesia dibandingkan dengan ketika melakukan pembelajaran daring murni. Tingkat pilihan kurang setuju pada poin ini sangat rendah. Kelima, peserta didik juga menyatakan kesetujuannya bahwa guru menjelaskan secara langsung ketika pelaksanaan pembelajaran. Guru menjelaskan untuk peserta didik yang berada 
di sekolah juga peserta didik yang berada di rumah. Sehingga transfer informasi yang diperoleh antara kedua peserta didik tersebut sama dengan penggunaan model blended learning. Keenam, sebagian besar peserta didik setuju bahwa perangkat elektronik dan jaringan internet mereka mendukung untuk pembelajaran. Namun, masih ditemukan peserta didik yang kurang setuju sebanyak 18,8 \%. Persentase ini adalah yang paling banyak dibandingkan dengan enam poin lain yang ditanyakan. Peserta didik yang memilih tidak setuju adalah peserta didik yang belajar secara daring di rumah. Hal ini dikarenakan beberapa tempat tinggal peserta didik masih kurang baik jaringan internetnya. Selain itu, juga terdapat yang perangkatnya kurang mendukung untuk melakukan live meet. Ketujuh, peserta didik setuju bahwa dalam pelaksanaan blended learning guru sudah menyiapkan materi pembelajaran secara menarik. Materi ini disiapkan guru dalam bentuk, fail PPT, dokumen, video, atau suara yang diunggah melalui Simpel-12. Peserta didik yang melaksanakan pembelajaran di rumah dapat mengakses materi melalui Simpel-12 sembari mendengarkan penjelasan guru melalui live meet.

Secara keseluruhan, peserta didik setuju bahwa penggunaan model blended learning tepat digunakan untuk pembelajaran di era normal baru ini. Hal tersebut juga didukung oleh penelitian yang telah dilakukan Ferdiansyah et al. (2021), Budiyono (2020), dan Sari (2021). Penelitian-penelitian tersebut juga menjelaskan bahwa model blended learning efektif digunakan untuk pembelajaran di masa pandemi. Pembelajaran dengan blended learning dapat menumbuhkan sikap positif saat pembelajaran (Hsu Chen et al., 2017). Peserta didik tidak ada yang memilih tidak setuju. Namun, tidak dapat dipungkiri bahwa masih ada persentase peserta didik yang memilih kurang setuju di setiap pernyataan yang disampaikan. Salah satu faktor utama yang kerap menghambat penggunaan model blended learning adalah masalah jaringan internet dan perangkat yang tidak memadai. Penerapan model blended learning di SMAN 12 Semarang dapat terlaksana dengan baik karena di dukung peralatan yang memadai dari sekolah, masing-masing kelas sudah tersedia webcam, komputer, LCD proyektor, pengeras suara, dan Wi-Fi yang lancar. Pada saat pembelajaran praktik, peserta didik yang melaksanakan pembelajaran di rumah dapat menyaksikan dan turut memberi tanggapan atau komentar. Hal tersebut tentunya menambah ketertarikan peserta didik dalam mengikuti pembelajaran.

\section{Penutup}

Berdasarkan hasil pembahasan yang telah dijabarkan sebelumnya, maka dapat disimpulkan bahwa model blended learning merupakan model yang efektif untuk diterapkan di keadaan normal baru (new normal). Penerapan blended learning dilakukan dengan persentase 50\% F2F (Tatap muka) dan 50\% daring dari rumah masing-masing. Kesuksesan penerapan model blended learning tersebut juga di dukung oleh perangkat yang memadai, jaringan internet yang bagus, dan sumber daya yang memadai. Model blended learning dapat diterapkan pada sekolah untuk pelaksanaan pembelajaran synchronous. Jika perangkat yang digunakan tidak mendukung, dapat menjadi salah satu faktor 
pembelajaran blended learning tidak berjalan dengan lancar. Penggunaan Simpel-12 di SMAN 12 Semarang juga sudah mendapat tanggapan baik dari para orang tua peserta didik sebagian peserta didik setuju bahwa pemahaman mereka meningkat terhadap materi bahasa Indonesia ketika menggunakan platform Simpel-12 saat blended learning.

\section{Daftar Pustaka}

Alammary, A., Sheard, J., \& Carbone, A. (2014). Blended Learning in Higher Education: Three Different Design Approaches. Australasian Journal of Educational Technology, 30(4), 440-454. https://doi.org/https://doi.org/10.14742/ajet.693

Budiyono, F. (2020). Implementasi Blended Learning di Masa Pandemi Covid 19. Prosiding Diskusi Daring Tematik Nasional 2020, 9-12. http://researchreport.umm.ac.id/index.php/psnpb/article/download/3640/3605

Dwiyogo, W. D. (2019). Pembelajaran Berbasis Blended Learning. Jakarta: Raja Grafindo Press.

Nilasari, K. E. (2020). Pembelajaran Bahasa Indonesia di Masa Pandemi Covid 19. Lentera: Jurnal Diklat Keagamaan Padang, 5(1), 15-28. https://lentera.kemenag.go.id/index.php/lentera/article/view/14

Ferdiansyah, H., Zulkifli N., Yakub, R., \& Agussalim, A. (2021). Penggunaan Model Blended Learning terhadap Hasil Belajar di masa Pandemi Covid-19. Edumaspul: Jurnal Pendidikan, 5(2), 329-334. https://doi.org/10.33487/edumaspul.v5i2.2075

Firmansyah, Y., \& Kardina, F. (2020). Pengaruh New Normal di Tengah Pandemi Covid-19 terhadap Pengelolaan Sekolah dan Peserta Didik. Jurnal Buana IImu, 4(2), 99-112. https://doi.org/10.36805/bi.v4i2.1107

Graham, C. R. (2006). Blended Learning Systems: Definition, Current Trends, and Future Directions. In Bonk, C. J., \& Graham, C. R. The Handbook of Blended Learning: Global Perspectives, Local Designs (pp. 3-21). San Francisco, CA: Pfeiffer Publishing.

Halimah, S. (2019). Desain Pembelajaran Berbasis Blanded Learning di Perguruan Tinggi. Prosiding Seminar Nasional Fakultas IImu Sosial Universitas Negeri Medan, 3, 680-685. http://digilib.unimed.ac.id/39396/1/02.-Siti-Halimah.pdf

Haryadi. (2012). Dasar-Dasar Membaca. Semarang: Unnes Press.

Hendarrita, Y., Indranurwati, A., \& Purwanto, P. (2018). Rancangan Model Pembelajaran Blended Learning Dengan Media Blog. Jakarta: Pusat Teknologi Informasi dan Komunikasi Pendidikan dan Kebudayaan, Kementerian Pendidikan dan Kebudayaan.

Hilmi, D., \& Ifawati, N. I. (2020). Using the Blended Learning as an Alternative Model of Arabic Language Learning in the Pandemic Era. Arabi : Journal of Arabic Studies, 5(2), 117-129. https://doi.org/10.24865/ajas.v5i2.294

Hsu Chen, C., Yen Huang, C., \& Yu Chou, Y. (2017). Integrating Augmented Reality into Blended Learning for Elementary Science Course. ICIET '17: 
Proceedings of the 5th International Conference on Information and Education Technology, 68-72. https://doi.org/10.1145/3029387.3029417

Jalinus, N., Verawardina, U., Krismadinata, Azis Nabawi, R., \& Darma, Y. (2021). Developing Blended Learning Model in Vocational Education Based On 21st Century Integrated Learning and Industrial Revolution 4.0. Turkish Journal of Computer and Mathematics Education, 12(9), 1276-1291. https://doi.org/10.17762/turcomat.v12i9.3480

Kanuka, H., \& Rourke, L. (2013). Using Blended Learning Strategies to Address Teaching Development Needs: How Does Canada Compare?. Canadian Journal of Higher Education, 43(3), 19-35. https://doi.org/10.47678/cjhe.v43i3.184741

Mahmud, H. (2017). Upaya Meningkatakan Keterampilan Menulis Dengan Teknik RCG (Reka Cerita Gambar) Pada Siswa Kelas VI SDN Rengkak Kecamatan Kopang, Kabupaten Lombok Tengah Tahun Pelajaran 2017/2018. JISIP: Jurnal IImu Sosial dan Pendidikan, 1(2), 32-46. http://ejournal.mandalanursa.org/index.php/JISIP/article/view/178

Narayana, I. W. G. (2016). Analisis terhadap Hasil Penggunaan Metode Pembelajaran Synchronous dan Asynchronous. Seminar Nasional Teknologi dan Multimedia (Semnasteknomedia) 2016, 139-144. https://ojs.amikom.ac.id/index.php/semnasteknomedia/article/view/1255

Pawicara, R., \& Conilie, M. (2020). Analisis Pembelajaran Daring terhadap Kejenuhan Belajar Mahasiswa Tadris Biologi IAIN Jember di Tengah Pandemi Covid-19. Alveoli: Jurnal Pendidikan Biologi, 1(1), 29-38. https://doi.org/10.35719/alveoli.v1i1.7

Sari, I. K. (2021). Blended Learning sebagai Alternatif Model Pembelajaran Inovatif di Masa Post-Pandemi di Sekolah Dasar. Jurnal Basicedu, 5(4), 2156-2163. https://doi.org/10.31004/basicedu.v5i4.1137

Siahaan, M. (2020). Dampak Pandemi Covid-19 terhadap Dunia Pendidikan. Jurnal Kajian IImiah, 1(1), 1-6. https://doi.org/10.31599/jki.v1i1.265

Sugiyono. (2017). Metode Penelitian Pendidikan. Bandung: Penerbit Alfabeta.

Tarigan, G. H. (2008a). Berbicara sebagai Suatu Keterampilan Berbahasa. Bandung: Angkasa.

Tarigan, G. H. (2008b). Menyimak sebagai Suatu Keterampilan Berbahasa. Bandung: Angkasa.

Triyanto. (2020). Analisis Kebijakan Pembelajaran Jarak Jauh pada Pelajaran Bahasa Indonesia di Masa Wabah Virus Corona. Diglosia: Jurnal Kajian Bahasa, Sastra, dan Pengajarannya, 3(4), 393-402. https://doi.org/10.30872/diglosia.v3i4.100

Yanti, N., Suhartono, S., \& Kurniawan, R. (2018). Penguasaan Materi Pembelajaran Keterampilan Berbahasa Indonesia Mahasiswa S1 Program Studi Pendidikan Bahasa dan Sastra Indonesia FKIP Universitas Bengkulu. Jurnal IImiah Korpus, 2(1), 72-82. https://doi.org/10.33369/jik.v2i1.5559 